Int.J. Hum. Soc. Dev. Res.

ISSN(P):2521-1439; ISSN(E):2523-4331

Volume 5, Number 2, 2021. 106-115

DOI: $10.30546 / 2523-4331.2021 .5 .2 .106$

\title{
SLUM SETTLEMENTS PROBLEM IN DEVELOPING SUSTAINABILITY OF THE CITY OF MEDAN
}

\section{Ali Musri S}

University of Pembinaan Masyarakat Indonesia (UPMI), Medan, North Sumatera, Indonesia

\section{ABSTRACT}

Making a health living environment in a city is a challenge for city planners. This study was conducted to collect the data of slum settlement problems in Medan City of Indonesia. A survey method was applied to seek the data of slum settlements. It was noted that out of $40 \%$ of the low-income population, $4.28 \%$ of households live in uninhabitable urban environments and $15.52 \%$ of households live in uninhabitable rural environment. Data showed that the most rapid increase in population density in the past year is in the areas of Medan Helvetia (110.32 people / km2), Medan Amplas (143.27 people / km2) and Medan Timur (72.65 people / km2). These three areas have a great opportunity to generate some illegal settlements and make them slum areas. As a result, it makes the Medan City could not provide the inadequate infrastructure due to the rising number of people living in slum settlements. It concludes that the City of Medan has been dealing with the problem of slum and squatter settlements.

C2021.All rights reserved.

\section{ARTICLE HISTORY}

Received: 02/03/2021

Accepted: 11/08/2021

Published online: 01/10/2021

\section{KEYWORDS}

Environment; problems; settlements; uninhabitable; urban; slum 


\section{Introduction}

Development is an indicator that determines whether an area is progressing or not. The progress of an area is determined by the presence or absence of changes or improvements that occur in social and economic aspects. The increase that occurred in the economic aspect was marked by an increase in the income of the people per capita compared to the rate of population growth. Fundamentally, the economic structure determines the level of economic development of a country as seen from the level of income distribution of the population in a country.

As for the increase in the social aspect, it is marked by an increase in the quality of human life in a complete manner, so that human needs in the form of physical needs and social needs can be met. Contextually, social development refers to a social justice system rather than an economic system (Migley, 1995). If these two aspects (economic and social) have increased, then an area can be said to have progressed and developed towards an urban area.

The development of the urban area can become an attraction for economic and social activities for people living in the surrounding area. This can have an impact on people's lives, for example, the mobility of the flow of labor which results in increased urbanization. Uncontrolled urbanization will cause a population explosion. Another impact is the increasing need for settlements in urban areas. The large demand for housing will then have its own impact on the development of urban areas, especially if the complete infrastructure and available vacant land are inadequate.

Most of the urbanists who came were laborers and traders. Based on data from the Medan City Statistics Agency, information is obtained that there are 17,958 residents who are traders and 23,108 residents are private employees (2). Most of the workers and traders are from the middle to lower economic class. They will look for a place to live close to the center of trade or industrial center to reduce the high cost of living. 
The need for settlements in central trade and industrial centers cannot be matched by the availability of adequate housing facilities. In general, the availability of vacant land which can be used as settlement in commercial and industrial areas is very minimal. This resulted in the emergence of densely populated settlements with inadequate infrastructure that seemed slum.

A settlement is said to be slum if: the quality of the road surface is in the bad category so that it cannot serve the entire residential environment; unavailability of access to drinking water for the community and if there is, it does not meet drinking water standards; the available drainage system is not well maintained so that during the rainy season many puddles appear containing household waste (solid or liquid); waste management that is not good so that a lot of garbage piles are found in the area; as well as the inadequacy of the protection system against fire hazards, both related to road access for fire engines, as well as the availability of firefighting systems in the area (Oktavia \& Warlina, 2017).

Based on the report of the North Sumatra Central Statistics Agency in 2019, it was noted that out of $40 \%$ of the low-income population, $4.28 \%$ of households live in uninhabitable urban environments and $15.52 \%$ of households live in uninhabitable rural environments (4). This means that the city government and local governments are still not serious in overcoming the problem of slum settlements. Some areas that are commonly said to be slum settlements are illegal settlements (illegal), namely settlements built on state-owned lands that are not actually used as settlements, such as settlements on riverbanks, on land owned by PT. Kereta Api Indonesia, PTPN, under elevated roads, and around city parks and other green open land (Wajib, 2016).

According to Patrick McAuslan [6], the presence of squatter settlements will develop into slums starting from: the organization of people to live in squatter settlements; the existence of families living on land that is not occupied with or without permission from the land owner; and squatter settlements based on official orthodox transactions. In principle, illegal settlements are growing very rapidly, because they are based on a sale and purchase agreement for a plot of land, but are carried out without a 
legal agreement regarding the distribution of land area legally, because the land seller is not the legal owner of the land (McAuslan, 1987).

Therefore, it is very difficult for the government to deal with the problem of slum and squatter settlements. Some of the reasons include: first, the cost of compensation for high-rise buildings is very large; second, slum renovation is a large project; third, the dualism between environmental rejuvenation and environmental management; fourth, there are many renovation of slum neighborhoods that do not go through a social survey on the characteristics of the population who will be displaced; fifth, there are many slum renovations that pay less attention to public facilities; sixth, the personnel engaged in the slum renovation program are not professional; seventh, squatter clearance is often interpreted as bad, even though the government is trying to rejuvenate the environment and resettle people to a better environment; eighth, limited land (land shortage); ninth, the lack of housing development funds (no housing finance); and tenth, there is still minimal togetherness between citizens (McAuslan, 1987).

\section{Method}

This research was applied a survey method; it explores the phenomena that occur in society to be described so that it can answer the problems under study. To stay focused on the research objectives, a research instrument in the form of a questionnaire and questionnaire was developed so that it can be described.

\section{Results and Discussion}

The City of Medan is one of the cities with a high population density as according to the Central Statistics Agency in 2010 it was 7915.5 people / Km2 to 8541 people / $\mathrm{Km} 2$ in 2018 and 8600.13 people / Km2 in 2019. Medan City is divided into 21 (twenty one) administrative areas with the highest population density are in ten administrative areas, including: Medan Amplas, Medan Helvetia, Medan Barat, Medan Maimun, Medan Kota, Medan Timur, Medan Denai, Medan Tembung, Medan Area and Medan Perjuangan as referred to stated in table 1 below. 
Table 1. Increasing Population Density of the City of Medan in 2018 - 2019

\begin{tabular}{lccr}
\hline \multicolumn{1}{c}{ Districts } & \multicolumn{2}{c}{ Population density $\left(\mathbf{p e o p l e} / \mathbf{k m}^{\mathbf{2}}\right)$} \\
& $\mathbf{2 0 1 8}$ & $\mathbf{2 0 1 9}$ & Increasing \\
\hline 1. Medan Amplas & 11557,00 & 11700,27 & 143,27 \\
2. Medan Helvetia & 11701,00 & 11811,32 & 110,32 \\
3. Medan Barat & 13776,00 & 13796,62 & 20,62 \\
4. Medan Maimun & 13789,00 & 13805,03 & 16,03 \\
5. Medan Kota & 14261,00 & 14275,33 & 14,33 \\
6. Medan Timur & 14495,00 & 14567,65 & 72,65 \\
7. Medan Denai & 16351,00 & 16401,99 & 50,99 \\
8. Medan Tembung & 17382,00 & 17427,91 & 45,91 \\
9. Medan Area & 18115,00 & 18163,41 & 48,41 \\
10. Medan Perjuangan & 23679,00 & 23714,18 & 35,18 \\
\hline Population density of the City of & $\mathbf{8 5 4 1}$ & $\mathbf{8 ~ 6 0 0 , 1 3}$ & $\mathbf{5 9 , 1 3}$ \\
Medan & & & \\
\hline Source: Central Statistics Agency [7] & & & \\
\hline
\end{tabular}

Based on table 1 above, it is known that the most rapid increase in population density in the past year is in the areas of Medan Helvetia (110.32 people / km2), Medan Amplas (143.27 people / km2) and Medan Timur (72.65 people / km2). This shows that these three areas are a great opportunity to generate illegal settlements which also make them slum areas. Another aspect that is involved in the formation of other slum settlements can also be seen from the number of families living in the city of Medan, as shown in table 2 below.

Table 2. Occupation based on population and number of families in Medan City Region in 2019

\begin{tabular}{lrr}
\hline \multicolumn{1}{c}{ Districts } & Total Population & Total Families \\
\hline 1. Medan Labuhan & 122.192 & 26.804 \\
2. Medan Sunggal & 117.535 & 27.637 \\
3. Medan Selayang & 111.052 & 28.862 \\
4. Medan Amplas & 130.926 & 29.461 \\
5. Medan Johor & 137.367 & 31.177 \\
6. Medan Tembung & 139.249 & 31.574 \\
7. Medan Denai & 148.438 & 33.159 \\
8. Medan Helvetia & 155.437 & 34.125 \\
9. Medan Marelan & 175.382 & 37.045 \\
10. Medan Deli & 190.971 & 42.446 \\
\hline
\end{tabular}

Source: Central Statistics Agency [7]

Int.J. Hum. Soc. Dev. Res. Volume 5, № 2, 2021.106-115 
The number of families shows the number of settlements in an area, whether it is by renting or by owning their own house. The more families living in an area, the more houses are in that area. Based on table 2 above, it can be stated that the ten regions with the highest number of families are: Medan Labuhan, Medan Sunggal, Medan Selayang, Medan Amplas, Medan Johor, Medan Tembung, Medan Denai, Medan Helvetia, Medan Marelan, and Medan Deli.

For example, in the areas of Medan Denai, Medan Helvetia, Medan Marelan and Medan Deli, there are arable land that has long been inhabited by the community as an illegal settlement area and currently these residential areas have become slum settlements. Some of the reasons that an area that is cultivated land is said to be a slum settlement, among others:

\section{Residential building conditions}

As stated by McAuslan [6], illegal settlements do not have clear boundaries in terms of ownership of land area, because the structure of buildings in arable land areas does not have an orderly shape like building structures in general. Likewise with the existing building forms, in general those who live on arable land do not really consider the shape of the building they occupy. Most of the existing buildings are semipermanent or permanent buildings without plaster, so they seem untidy and irregular. This is what causes the buildings in the area to look slum.

\section{Environmental road conditions}

Settlements that are located on cultivated land are seen as illegal areas so that it is not uncommon for many residents to have no clear population administration, so that in this case the need for road infrastructure does not get too much attention from the government. Therefore, the roads that are available to access these settlements are the result of self-help from the surrounding communities so that they are not suitable roads. Some of them are just paths / dirt roads lined with gravel or crushed stone. When the rainy season arrives, the road is often filled with water, making it very difficult for motorized vehicles to pass. 


\section{Availability of drinking water}

Settlements that are located on arable land also do not have access to clean water provided by the local government, because there is no clear population administration. Therefore, the occupation looked for other alternatives such as drilling wells to meet their needs for clean water. However, in some cases that are considered very few, there are still people who meet their needs for clean water through the nearest river basin (DAS) in their area and a small proportion have access to clean water provided by local governments.

\section{Drainage conditions}

The availability of drainage is a vital aspect in zoning. Therefore, a settlement can be considered slum if the drainage in an area is not maintained, causing a narrowing, silting, or even blockage which can result in flooding in the area. The drainage conditions in arable land areas are generally only intended for disposal of existing water in each household, sometimes they are not connected to each other so that there is a very big chance of creating flooding in the rainy season.

\section{Waste management}

Apart from the absence of drainage in the arable land area, there is also no proper waste management system in that area. In general, people who live have their own garbage dumps to be burned. Such waste management has more of a negative impact on health. Garbage that is piled up will cause an unpleasant odor to the environment in which you live. If it is burned, it will cause a lot of smoke which can interfere with the breathing of the people around it.

\section{Protection against fire}

Difficult road access to arable land areas, the lack of water availability, and the density of settlements in arable land are obstacles in overcoming fire problems. This is a challenge in itself for residents who live in the area to overcome the fire problem. Therefore, the community independently maintains the possibility of a fire and tries to avoid or dispel the possibility of a fire. 
The six conditions described above make this area very difficult to develop and become a destination for regional development. The growth of slum settlements is expected to have a major impact on human life and environmental sustainability. On the one hand, the condition of the slum settlements itself contains a physical threat in the form of natural disasters such as floods which are basically the result of human behavior in treating their environment. Human treatment of the environment in question is the construction of housing that is not suitable for its residents (Napier, 2007). The low capacity of slum dwellers to recover from potential disasters, such as floods and earthquakes, makes it difficult to carry out sustainable development in slum areas. This will be different when compared to a more formal community (Ajibade \& McBean, 2014), (Ebert, Kerle, \& Stein, 2009).

On the other hand, residents of slum settlements themselves can also be affected by their bad environment due to the lack of basic services such as health services and administrative services. The existence of slum settlements can also lead to soil, air and water drainage pollution caused by burning garbage and household waste that has stagnated due to poor drainage management. This has resulted in a continuing cycle of decline for both slum dwellers and the environment (Ali, M. \& Sulaiman, 2006), with the likely impact of extending to communities outside the slum (e.g. floods). The growth and expansion of slum settlements can therefore threaten sustainable urban development at local, national and regional scales (Patel, 2012).

The growth and expansion of slum settlements can also have an impact on the national and regional economies, both negatively and positively. For example, the negative aspect of slum settlements relates to the fact that they are often burdened with high transaction costs, including increases in transportation spending. The result of inadequate infrastructure and disease burden on urban residents is due to the large number of people living in slum settlements (Fox, 2008). In addition, ambiguous property rights and leases can reduce the efficiency of urban land and housing markets, and can inhibit investment or reduce participation in urban labor markets (Marx, Stoker \& Suri, 2013). This has the potential to affect the economic prospects of a country or region as a whole in the global economy, making it less competitive in the world arena (15). 
Sustainability, as suggested by the SDGs, is only achieved through implementing comprehensive integrated solutions that provide better results for multiple purposes. Successful responses must be based on recognizing the multiple forces behind different types of slum settlements and the need to implement multiple policy tools (social, economic, physical and community) simultaneously. For such joint integration to be effective, they must be sandwiched by a long-term strategy to achieve broader societal goals based on the principles of sustainability. Therefore, positive slum upgrading and reform should not only be about providing housing and infrastructure but rather prioritizing the economic, social and community activities needed to reverse the downward trend in an area. Such an approach can indeed lead to urban regeneration at the regional level and have an impact on the urban structure of the city as a whole.

\section{Conclusion}

It concludes that the City of Medan has been dealing with the problem of slum and squatter settlements. It makes the Medan City could not provide the inadequate infrastructure due to the rising number of people living in slum settlements. Lack of infrastructure resulted in the low quality of life in the slum areas and declined the environment conditions.

\section{Disclosure statement}

No potential conflict of interest was reported by the author.

\section{Contact Information}

E-mail: malimusri@gmail.com 


\section{References and notes:}

Migley, J. (1995). Social Development: The Developmental Perspective in Social Welfare. London:: Sage Publications Ltd. Page 1-10.

Central Statistics Agency. (2020). Kota Medan dalam Angka 2020. Medan: Badan Pusat Statistika Kota Medan.

Oktavia, D., \& Warlina, R. (2017). Identifikasi Pemukiman Kumuh dan Alternatif Penataan di Kelurahan Cijorolebak: Studi Kasus Sempadan Sungai Ciujung. Jurnal Wilayah dan Kota, 4 (2) , 105-114.

Central Statistics Agency. (2019). Indikator Tujuan Pembangunan Berkelanjutan Provinsi Sumatera Utara. Medan: Badan Pusat Statistik Provinsi Sumatera Utara.

Wajib, N. (2016). Pemukiman Kumuh dan Liar, mau diapakan? Medan: Kementerian Pekerjaan Umum dan Perumahan Rakyat. Retrieved from: http://kotaku.pu.go.id:8081/wartaarsipdetil.asp?mid=8368\&catid=2\&.

McAuslan, P. (1987). Urban land and shelter for the poor. London: Earthscan.

Central Statistics Agency. (2020). Kecamatan Medan Kota dalam Angka Tahun 2019. Medan: Badan Pusat Statistika Kota Medan.

Napier, M. (2007). Informal settlement integration, the environment and sustainable livelihoods in Sub-Saharan. Montreal, Canada: University of Montreal. Retrieved from http://www.grif.umontreal.ca/pages/irec\%20papers/napier.pdf.

Ajibade, I., \& McBean, G. (2014). Climate extremes and housing rights: A political ecology of impacts, early warning and adaptation constraints in Lagos slum communities. Geoforum, 55, 76-86. doi:10.1016/j.

Ebert, A., Kerle, N., \& Stein, A. (2009). Urban social vulnerability assessment with physical proxies and spatial metrics derived from air- and spaceborne imagery and GIS data. Natural Hazards, 48, doi:10.1007/s11069-008-9264-0. , 275-294.

Ali, M. H., \& Sulaiman, M. S. (2006). The causes and consequences of the informal settlements in Zanzibar. XXIII Congress of the International Federation of Surveyors, . Munich, Germany,: Retrieved from https://www.fig.net/resources/proceedings/fig_proceedings/fig2006/papers/ts35/ts 35_01_ali_sulaiman_0320.pdf.

Patel, A. (2012). Slumulation: An integrated simulation framework to explore spatio-temporal dynamics of slum formation in Ahmedabad. Korea: Dissertation. George Mason University.

Fox, S. (2008). On the origins and consequences of slums. In Centre for the study of African economies - economic development in Africa conference. Oxford, UK: Center for the Study of African Economies.

Marx, B., Stoker, T., \& Suri, T. (2013). The economics of slums in the developing world. Journal of Economic Perspectives, 27 , 187-210. doi:10.1257/jep.27.4.187.

Gambo, Y. L., Idowu, O. B., \& Anyakora, I. M. (2012). Impact of poor housing condition on the economy of the urban poor: Makoko, Lagos State in view. Journal of Emerging Trends in Economics and Management Sciences, 3 , 302-307. 